\title{
BIII-Tubulin: A novel mediator of chemoresistance and metastases in pancreatic cancer
}

\author{
Joshua A. McCarroll2,3,*, George Sharbeen ${ }^{1, *}$, Jie Liu1 ${ }^{1, *}$, Janet Youkhana ${ }^{1}$, David \\ Goldstein $^{1,4}$, Nigel McCarthy ${ }^{2}$, Lydia F. Limbri ${ }^{1}$, Dominic Dischl ${ }^{5}$, Güralp O. Ceyhan ${ }^{5}$, \\ Mert Erkan ${ }^{6}$, Amber L. Johns ${ }^{7}$, Andrew V. Biankin ${ }^{7,8}$, Maria Kavallaris ${ }^{2,3}$ and Phoebe \\ A. Phillips ${ }^{1}$ \\ ${ }^{1}$ Pancreatic Cancer Translational Research Group, Lowy Cancer Research Centre, Prince of Wales Clinical School, University \\ of New South Wales (UNSW Australia), Sydney, Australia \\ ${ }^{2}$ Children's Cancer Institute, Lowy Cancer Research Centre, UNSW Australia, Sydney, Australia \\ ${ }^{3}$ ARC Centre of Excellence in Convergent Bio-Nano Science and Technology, Australian Centre for NanoMedicine, UNSW, \\ Australia \\ ${ }^{4}$ Prince of Wales Hospital, Prince of Wales Clinical School, Sydney, NSW, Australia \\ ${ }^{5}$ Department of Surgery, Klinikum Rechts der Isar, Technische Universität München, Munich, Germany \\ ${ }^{6}$ Department of Surgery Koc University School of Medicine, Istanbul, Turkey \\ 7 The Kinghorn Cancer Centre, Cancer Program, Garvan Institute of Medical Research, Darlinghurst, Sydney, Australia \\ ${ }^{8}$ Wolfson Wohl Cancer Research Centre, Institute of Cancer Sciences, University of Glasgow, Garscube Estate, Switchback \\ Road, Bearsden, Glasgow, Scotland G61 1BD, United Kingdom \\ * These authors contributed equally to this work \\ Correspondence to: Phoebe A.Phillips, email: p.phillips@unsw.edu.au
}

Maria Kavallaris, email:m.kavallaris@ccia.unsw.edu.au

Keywords: Pancreatic cancer, chemoresistance, tumor growth, metastases, $\beta$ lll-tubulin

Received: September 25,2014 Accepted: December 09,2014 Published: December 10, 2014

This is an open-access article distributed under the terms of the Creative Commons Attribution License, which permits unrestricted use, distribution, and reproduction in any medium, provided the original author and source are credited.

\section{ABSTRACT}

Pancreatic cancer is a leading cause of cancer-related deaths in Western societies. This poor prognosis is due to chemotherapeutic drug resistance and metastatic spread. Evidence suggests that microtubule proteins namely, $\beta$-tubulins are dysregulated in tumor cells and are involved in regulating chemosensitivity. However, the role of $\beta$-tubulins in pancreatic cancer are unknown. We measured the expression of different $\beta$-tubulin isotypes in pancreatic adenocarcinoma tissue and pancreatic cancer cells. Next, we used RNAi to silence $\beta$ III-tubulin expression in pancreatic cancer cells, and measured cell growth in the absence and presence of chemotherapeutic drugs. Finally, we assessed the role of $\beta$ III-tubulin in regulating tumor growth and metastases using an orthotopic pancreatic cancer mouse model. We found that $\beta$ III-tubulin is highly expressed in pancreatic adenocarcinoma tissue and pancreatic cancer cells. Further, we demonstrated that silencing $\beta I I I-t u b u l i n$ expression reduced pancreatic cancer cell growth and tumorigenic potential in the absence and presence of chemotherapeutic drugs. Finally, we demonstrated that suppression of $\beta I I I-t u b u l i n$ reduced tumor growth and metastases in vivo. Our novel data demonstrate that $\beta$ III-tubulin is a key player in promoting pancreatic cancer growth and survival, and silencing its expression may be a potential therapeutic strategy to increase the long-term survival of pancreatic cancer patients. 


\section{INTRODUCTION}

Pancreatic ductal adenocarcinoma (PDA) is a devastating disease that ranks as the fourth leading cause of cancer-related death in Western societies, with a 5-year survival rate of 6-7\% [1-5]. This poor prognosis is due to PDA's propensity to acquire resistance to chemotherapeutic agents and metastasize [8, 9]. The result is that our current chemotherapeutic treatments only extend patient survival by $\sim 8-16$ weeks [10]. These statistics highlight the imperative to identify effective therapeutic targets for this devastating disease.

The tubulin/microtubule network is recognized as a key player in cancer chemoresistance [11]. Microtubules are tube-like assemblies of $\alpha$-and $\beta$-tubulin heterodimers, that form part of the cell cytoskeleton and play critical roles in regulating mitosis and intracellular transport [11]. $\beta$-tubulin has seven different isotypes ( $\beta \mathrm{I}, \beta \mathrm{II}, \beta \mathrm{III}, \beta \mathrm{IVa}$, $\beta \mathrm{IVb}, \beta \mathrm{V}, \beta \mathrm{VI})$ that exhibit distinct tissue expression profiles [11]. Notably, all of the $\beta$-tubulin isotypes share a high degree of homology and are distinguished by their unique carboxy terminal tail which is subject to post-translational modifications [11]. The importance of microtubules as therapeutic targets for cancer is highlighted by the clinical use of tubulin binding agents (TBAs) which target $\beta$-tubulin. At high concentrations these agents induce mitotic arrest and cause cell death [12]. However, therapeutic applications of TBAs are often marred by resistance, which is often correlated to differential expression of specific $\beta$-tubulin isotypes [11]. Clinical studies have reported high expression of $\beta$ IIItubulin in several cancers including lung, breast, prostate, gastric and melanoma [13-18]. Under non-pathological conditions $\beta$ III-tubulin expression is primarily restricted to neurons, and sertoli cells in the testis, and at low levels in other tissues $[19,20]$. Interestingly, its upregulation in cancer cells has been correlated to decreased progressionfree or overall survival and resistance to chemotherapeutic agents [21]. Functional studies have confirmed the importance of $\beta I I I-t u b u l i n$ in regulating sensitivity to chemotherapeutic agents in non-small cell lung cancer (NSCLC), ovarian cancer and prostate cancer cells [2225].

Up-regulation of $\beta I I I-t u b u l i n$ has been observed in advanced PDA patient tissue specimens and cell lines [26]. Interestingly, aberrant $\beta$ III-tubulin expression in PDA cells was associated with activation of kRAS (oncogene commonly associated with PDA) and appeared to be progressively upregulated in pancreatic intraepithelial neoplasias (PanIN) 1 to 3, the precursor lesions of PDA [26]. Despite this strong correlation, no functional role for $\beta$ III-tubulin has been established in pancreatic cancer. Using a gene-silencing approach we silenced $\beta$ III-tubulin expression in pancreatic cancer cells and determined its role in regulating chemosensitivity, cell growth, tumorigenesis and metastases. We report for the first time that silencing $\beta$ III-tubulin in pancreatic cancer cells in vitro 1) decreases clonogenicity; 2) decreases anchoragedependent and independent proliferation; 3) increases apoptosis and anoikis; and 4) increases sensitivity to chemotherapy drugs including gemcitabine and the TBAs paclitaxel and vincristine. Notably, we demonstrate the importance of $\beta I I I-t u b u l i n$ in regulating tumor growth and metastases in a clinically-relevant orthotopic pancreatic cancer mouse model.

\section{RESULTS}

\section{$\beta I I I-t u b u l i n$ is expressed in human pancreatic tumor cells}

$\beta I I I-t u b u l i n$ was expressed at high levels in pancreatic tumor cells, while absent in the acinar and normal ductal cells in PDA tissue (Figure 1A). To determine whether the expression pattern was specific to $\beta$ III-tubulin, we also examined the levels of another $\beta$-tubulin isotype, $\beta$ II-tubulin, which has been shown to be differentially expressed in tumor cells [27-29]. It too was present at high levels in pancreatic tumor cells, however in contrast to $\beta I I I-t u b u l i n$, it was also present in acinar and normal ductal cells (Supplementary Figure 1). Next, we measured $\beta I I I$-tubulin expression by western blotting in cell lysates from 3 different pancreatic cancer cell lines derived from primary (MiaPaCa-2, Panc-1) and metastatic (HPAF-II) sites. BIII-tubulin levels were significantly higher in all 3 pancreatic cancer cell lines compared to normal non-tumorigenic human pancreatic ductal epithelial (HPDE) cells (Figure 1B). $\beta$ II-tubulin was also higher in 2/3 pancreatic cancer cell lines (MiaPaCa-2 and Panc-1) compared to HPDE cells (Figure 1B). Notably, $\beta \mathrm{I}-$ tubulin, which is constitutively expressed in most tissues, was expressed at similar levels in the pancreatic cancer cell lines and the normal HPDE cells (Figure 1B).

\section{Potent and specific knockdown of $\boldsymbol{\beta}$ III-tubulin in pancreatic cancer cells}

To examine whether $\beta$ III-tubulin could be suppressed in pancreatic cancer cells, we transfected two-independent pancreatic cancer cell lines (MiaPaCa-2 and HPAF-II) with $\beta$ III-tubulin siRNA. $48 \mathrm{~h}$ and $72 \mathrm{~h}$ post transfection, $\beta$ III-tubulin expression was measured. Knockdown of $\beta$ III-tubulin was observed at the gene level in both cell lines (MiaPaCa-2, $84.4 \pm 2.6 \%$ knockdown; HPAF-II, $76.8 \pm 1.1 \%$ knock-down relative to control-siRNA; 72h post-transfection) (Figure 2A and B). This correlated to knockdown ( $>90 \%$ ) of $\beta$ III-tubulin at the protein level (Figure 2A and B). Knockdown of $\beta I I-$ tubulin was also observed when pancreatic cancer cells (MiaPaCa-2 and HPAF-II) were treated with $\beta$ II-tubulin 
siRNA (Supplementary Figure 2).

To confirm that knockdown of $\beta$ III-tubulin was specific and did not cause compensational changes in the expression of other major $\beta$-tubulin isotypes, MiaPaCa- 2 cells were transfected with $\beta$ III-tubulin siRNA and $72 \mathrm{~h}$ later the levels of total $\beta$-tubulin, $\beta$ I-tubulin and $\beta$ IItubulin were measured. No change in the expression of the above $\beta$-tubulins were observed following $\beta$ III-tubulin silencing (Figure 2C).

\section{$\beta$ III-tubulin silencing decreases clonogenicity and increases sensitivity to chemotherapeutic drugs in pancreatic cancer cells}

To establish the functional role of $\beta$ III-tubulin in pancreatic cancer, we determined the effect of silencing $\beta$ III-tubulin expression on the clonogenic potential of pancreatic cancer cells in the absence or presence of chemotherapeutic drugs. Silencing $\beta$ III-tubulin in the absence of chemotherapy significantly reduced the ability of pancreatic cancer cells (MiaPaCa-2 and HPAF-II) to form colonies compared to controls (Figures 3A and 3D). Moreover, the number of pancreatic cancer cell colonies was further decreased in the presence of the chemotherapy agents paclitaxel, vincristine, and gemcitabine (used in the first-line treatment of pancreatic cancer) when compared to controls (ns-siRNA) (Figures 3A-3F). In contrast, silencing $\beta$ III-tubulin had no effect on pancreatic cancer cell colony formation in the absence or presence of chemotherapy drugs (Supplementary Figure 3A-3F). Silencing $\beta$ III-tubulin or $\beta$ II-tubulin had no effect on cell viability or growth of normal non-tumorigenic HPDE cells (Supplementary Figure 4A and B). This suggests that BIII-

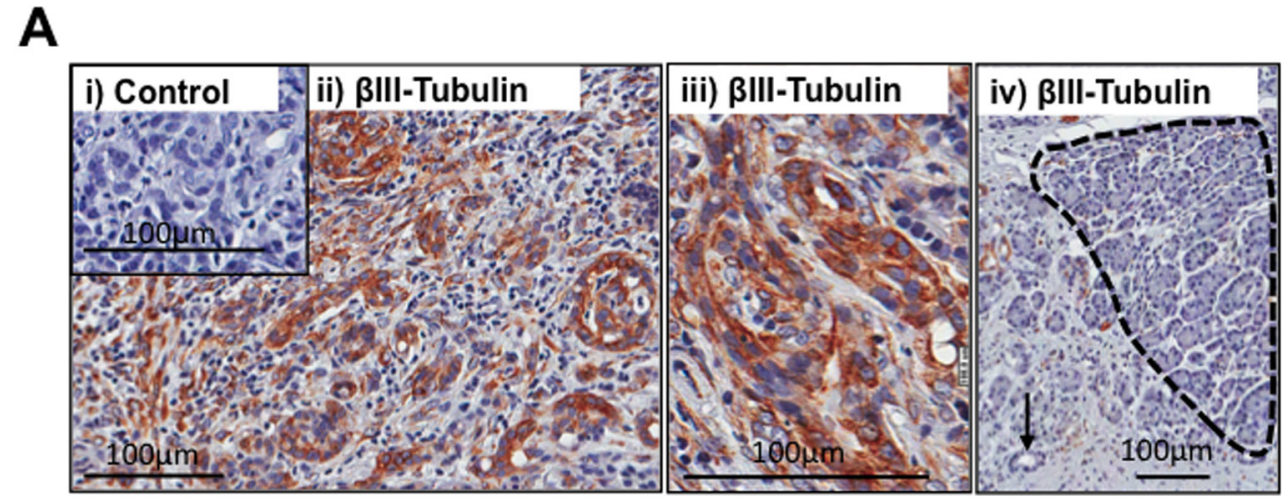

B
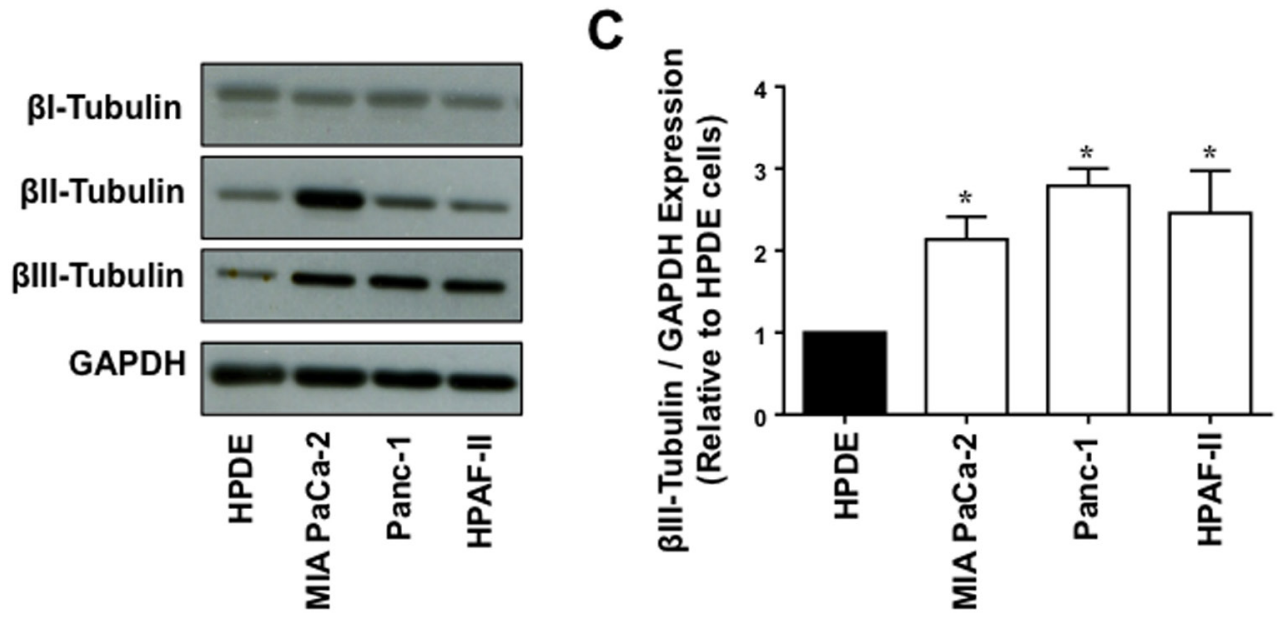

FIGURE 1: $\boldsymbol{\beta}$ III-tubulin expression in PDA patient tissue and PDA cell lines. A) Immunohistochemistry for $\beta$ III-tubulin in a representative human PDA tissue specimen. Panels show tissue stained with either isotype control antibody (i) or $\beta$ III-tubulin antibody (iiiv). The isotype control was negative and tumor elements had strong immunoreactivity for $\beta$ III-tubulin. Panel iv demonstrates an absence of $\beta$ III-tubulin staining in normal acinar cells (region marked by dashed border) and normal ductal cells (arrow) away from the tumor. B) Western blot analysis for $\beta \mathrm{I}-$, $\beta \mathrm{II}$-and $\beta \mathrm{III}-$ tubulin in protein extracts from pancreatic cancer cell lines (MIA Paca-2, Panc-1, HPAF-II) versus normal human non-tumorigenic pancreatic ductal epithelial cells (HPDE). GAPDH was used as a loading control. C) Densitometry analysis of $\beta$ III-tubulin expression normalized to GAPDH expression demonstrates that $\beta$ III-tubulin is significantly increased in all 3 pancreatic cancer cell lines compared to HPDE cells $(* \mathrm{p}<0.05 ; \mathrm{n}=3)$. 
tubulin may have a specific functional role in pancreatic cancer cells.

To determine whether silencing $\beta$ III-tubulin would affect the structure of the microtubule cytoskeleton of pancreatic cancer cells, MiaPaCa-2 and HPAF-II cells were transfected with $\beta$ III-tubulin- or control siRNA, and stained with fluorescent antibodies against total $\alpha$-tubulin (red) to visualize the microtubule cytoskeleton and $\beta$ IIItubulin (green). Suppression of $\beta$ III-tubulin, did not affect the structural integrity of the microtubule cytoskeleton (Figure 4A and 4B).

Next, we examined whether the increased sensitivity of pancreatic cancer cells to TBAs (paclitaxel and vincristine) following silencing of $\beta$ III-tubulin was due to increased disruption of mitosis. MiaPaCa-2 and HPAF-II cells were transfected with $\beta$ III-tubulin siRNA and then treated with increasing concentrations of
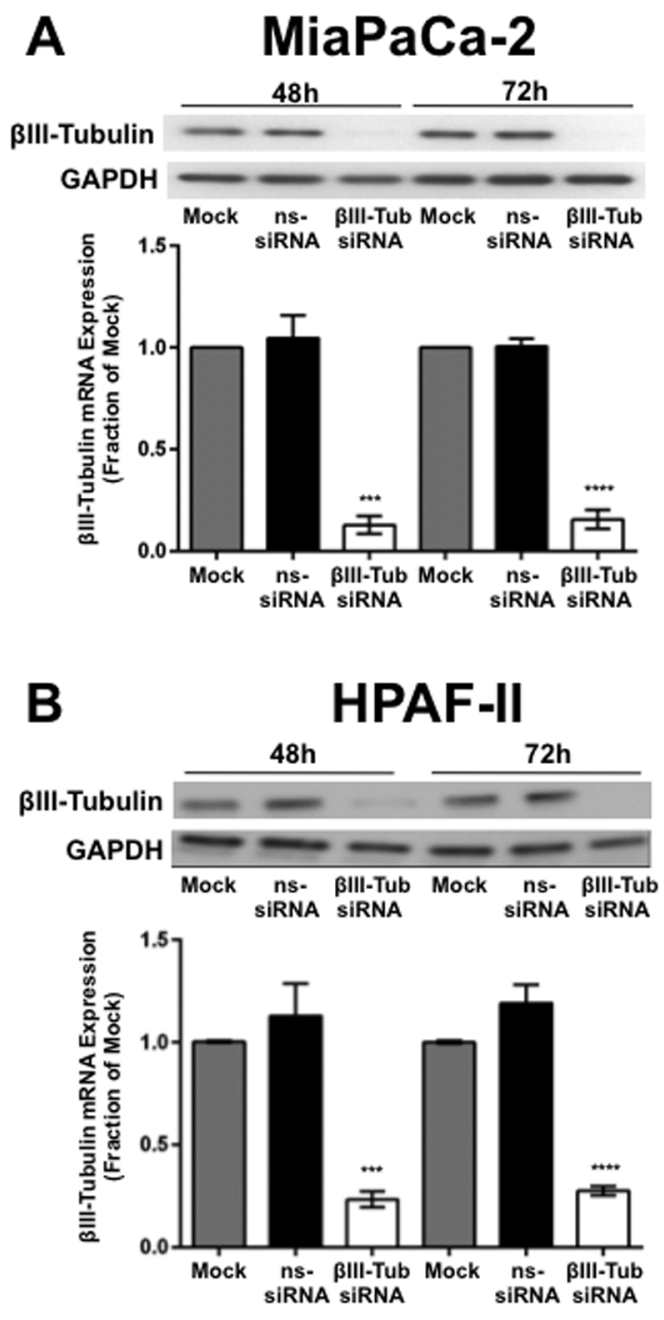

FIGURE 2: $\boldsymbol{\beta}$ III-tubulin silencing in pancreatic cancer cell lines. A) Top panel, Western blot analysis of $\beta$ III-tubulin silencing in protein extracts from MiaPaCa-2 cells. Cell lysates were harvested from cells $48 \mathrm{~h}$ or $72 \mathrm{~h}$ after transfection with mock, control siRNA (ns-siRNA), or $\beta$ III-tubulin siRNA ( $\beta$ III-Tub siRNA). GAPDH was used as a loading control. Bottom graph, real-time PCR analysis of $\beta I I I-t u b u l i n$ silencing in MiaPaCa-2 cells. RNA was harvested from cells $48 \mathrm{~h}$ or $72 \mathrm{~h}$ after transfection with mock, ns-siRNA, or $\beta$ III-tub siRNA. BIII-tubulin mRNA levels were normalized to 18S mRNA. B) as per A, except cell extracts were obtained from HPAF-II cells. Asterisks indicate significance $(* * \mathrm{p} \leq 0.01, * * \mathrm{p} \leq 0.01 ; \mathrm{n}=3)$. C) Representative Western blots for $\beta \mathrm{I}-, \beta \mathrm{II}-, \quad \beta \mathrm{III}$-tubulin and total tubulin in protein extracts from MiaPaCa-2 cells transfected with mock, ns-siRNA, or $\beta$ III-Tub siRNA (n=3). GAPDH was used as a loading control. paclitaxel (microtubule-stabilizing agent) or vincristine (microtubule-destabilizing agent) and their cell cycle measured. We observed increased accumulation of both control (ns-siRNA) and $\beta$ III-tubulin-siRNA treated cells in $\mathrm{G} 2 / \mathrm{M}$ phase, along with a corresponding decrease in G0/G1 phase with increasing concentrations of paclitaxel (Figure 4C) and vincristine (Figure 4D). However, $\beta$ IIItubulin knockdown did not markedly affect cell cycle distribution, relative to controls (ns-siRNA; Figure 4C$D)$, suggesting that the decreased clonogenic potential of $\beta$ III-tubulin knockdown cells in the absence or presence of TBAs was not due to enhanced disruption of the cell cycle.
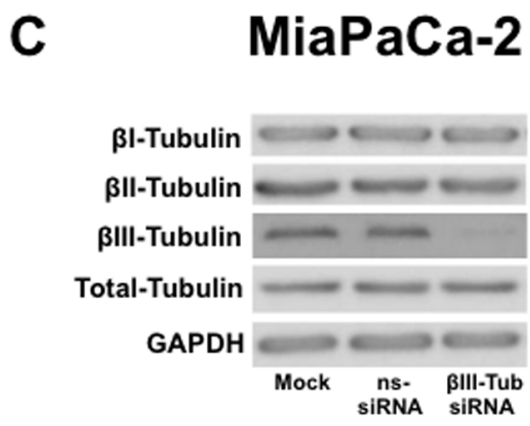


\section{$\beta I I I-t u b u l i n$ silencing induces apoptosis in} pancreatic cancer cells

To investigate whether apoptosis was responsible for the reduction in the number of pancreatic cancer cell colonies, MiaPaCa-2 cells were transfected with $\beta I I I-$ tubulin or control siRNA (ns-siRNA) and then treated with or without chemotherapy drugs. $\beta$ III-tubulin suppression in pancreatic cancer cells induced a marked increase in apoptosis (Annexin $\mathrm{V}$ and 7AAD) in the absence of chemotherapy drugs (Figure 5A-F). This was echoed by a significant increase in caspase 3/7 activity, in BIIItubulin knockdown cells (Figure 5D-F). Furthermore, the increase in apoptosis was sustained in the presence of chemotherapy drugs (Figure 5D-F). These data suggest that the decreased clonogenic potential in pancreatic cancer cells is mediated via increased apoptosis. To the best of our knowledge this is the first report to demonstrate a role for $\beta$ III-tubulin in regulating cell survival in tumor cells in the absence of chemical and /or environmental stress.

\section{$\beta I I I-t u b u l i n$ silencing reduces the tumorigenic potential of pancreatic cancer cells}

Our drug-clonogenic and apoptosis results suggested that $\beta$ III-tubulin might be playing a survival role in pancreatic cancer cells. Therefore, we investigated the effect of BIII-tubulin suppression on pancreatic cancer cell anchorage-dependent and -independent growth, as well as anoikis (anchorage-independent programmed cell death). Tumor cells with high tumorigenic and metastatic potential have acquired mechanisms to grow and survive under both anchorage-dependent and independent conditions, and develop mechanisms to resist anoikis. First, anchorage-dependent cell growth was
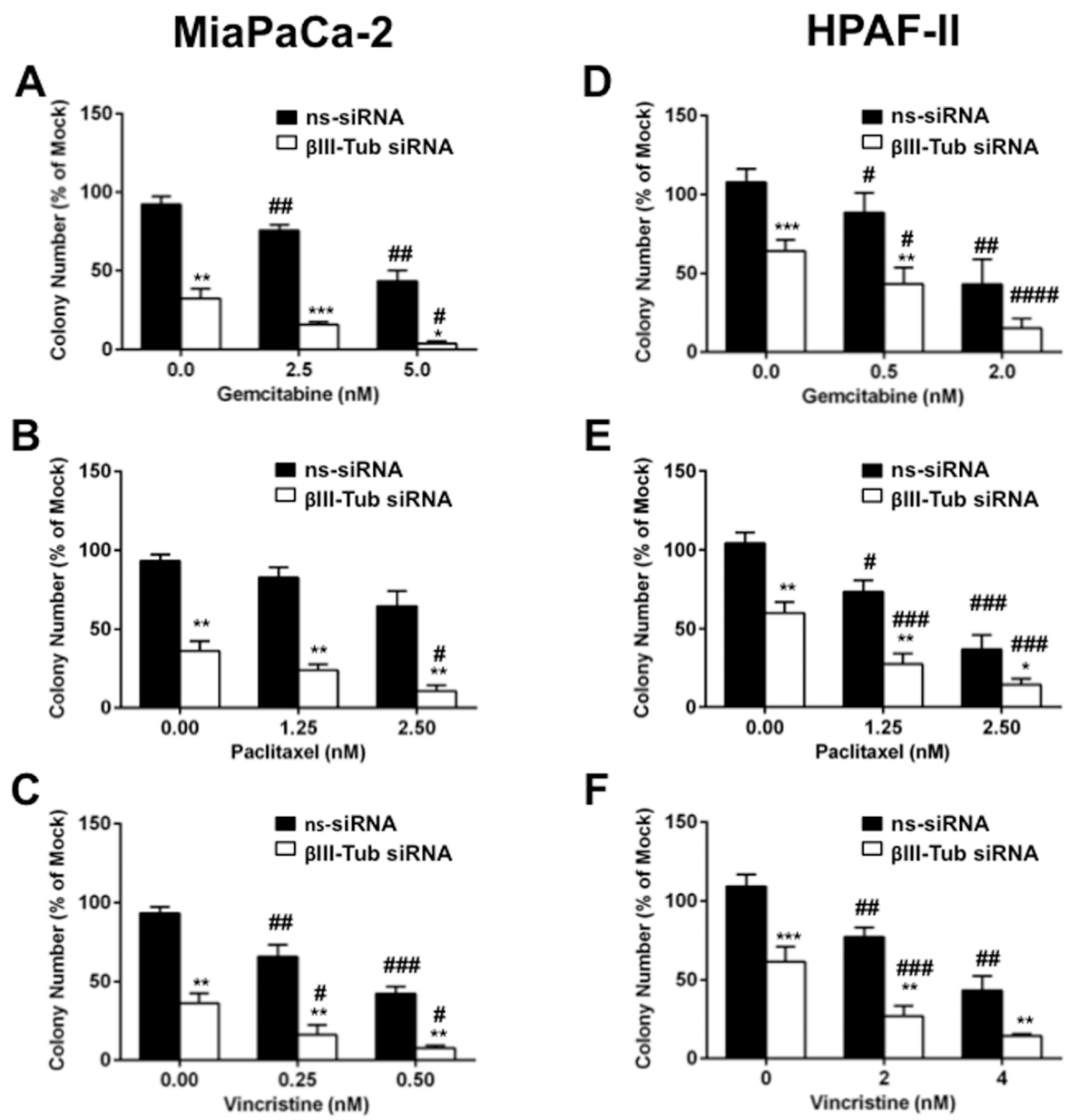

FIGURE 3: The effect of $\boldsymbol{\beta}$ III-tubulin silencing on pancreatic cancer cell clonogenic capacity. A-C) Bars represent the number of MiaPaCa-2 colonies (mean \pm s.e.m. as a $\%$ of mock) that formed from low density seeding following transfection with mock, control siRNA (ns-siRNA), or $\beta$ III-tubulin siRNA ( $\beta$ III-Tub siRNA) and 72h culture in titrations of Gemcitabine (A), Paclitaxel (B) or Vincristine (C). D-F) as per A-C, except experiments were carried out with HPAF-II cells. Asterisks indicate significance relative to nssiRNA of the same drug dose $(* * * \mathrm{p} \leq 0.001, * * * * \mathrm{p} \leq 0.0001 ; \mathrm{n}=5)$. Hashes indicate significance relative to $0 \mathrm{nM}$ drug concentration of the same siRNA (\# $\mathrm{p} \leq 0.05, \# \# \mathrm{p} \leq 0.01, \# \# \# \mathrm{p} \leq 0.0001 ; \mathrm{n}=5$ ). 
measured in real-time using the xCELLigence platform. Consistent with our drug-clonogenic results, we observed significantly reduced cell proliferation in MiaPaCa-2 cells transfected with $\beta$ III-tubulin siRNA relative to controls
(ns-siRNA) over 48h (Figure 6A). Next, we assessed the effects of $\beta$ III-tubulin knockdown on pancreatic cancer cell anchorage-independent growth. MiaPaCa-2 and HPAF-II cells were transfected with $\beta$ III-tubulin siRNA

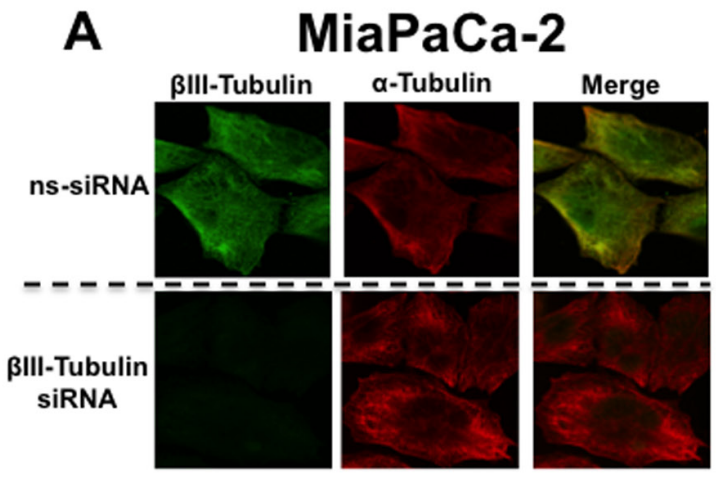

C
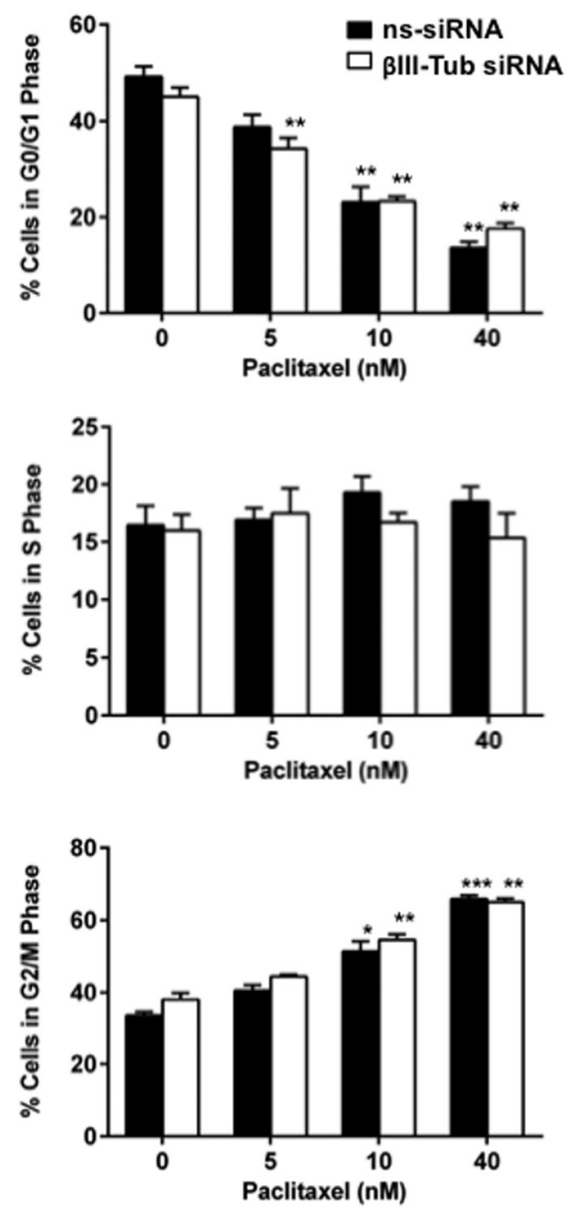

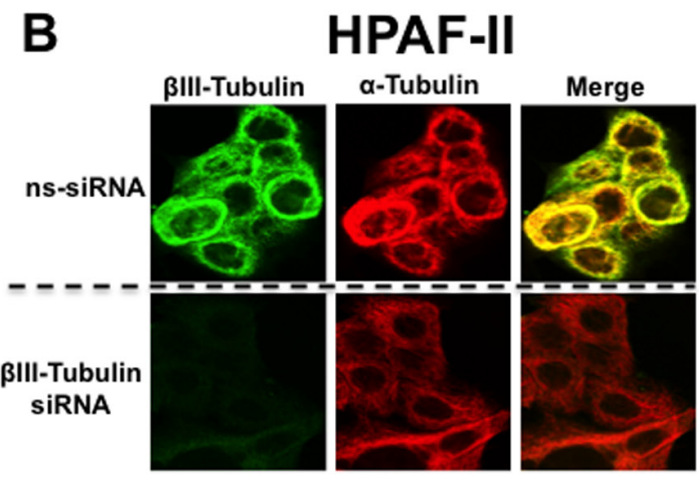

MiaPaCa-2
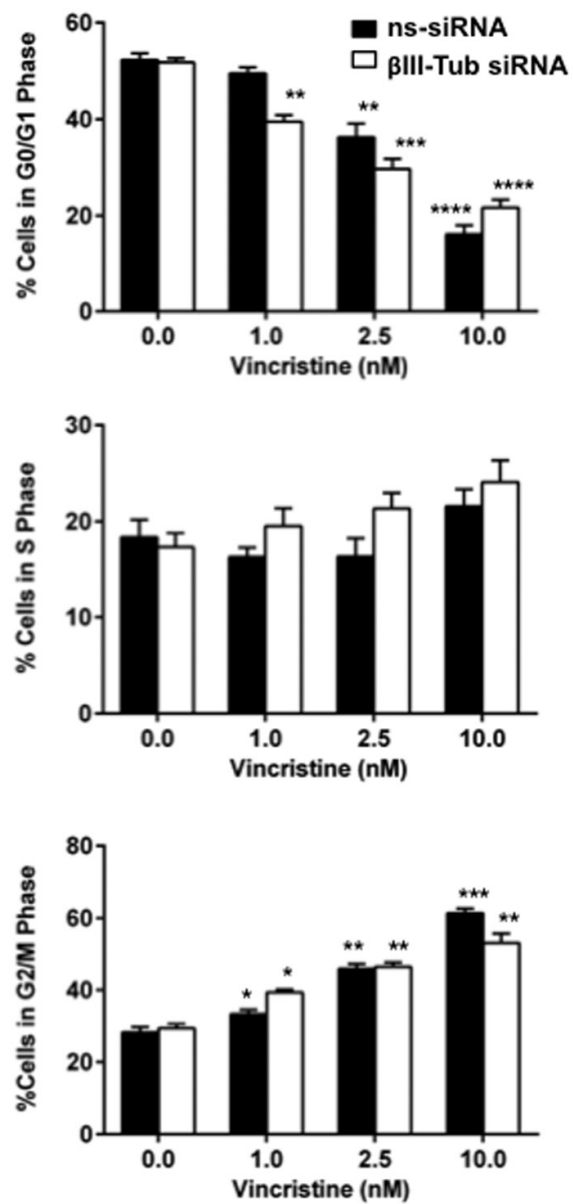

FIGURE 4: The effect of $\beta$ III-tubulin silencing on pancreatic cancer cell morphology and cell cycle. A) Confocal microscopy for $\alpha$-tubulin and $\beta$ III-tubulin in MiaPaCa-2 cells transfected with control siRNA (ns-siRNA) (top panels) or $\beta$ III-tubulin siRNA ( $\beta$ III-Tub siRNA; bottom panels). Overlaid fluorescence images are shown in the far right panel of each row. B) as per A, except HPAF-II cells were used. C-D) Cell cycle distribution was analyzed by propidium iodide staining and flow cytometry. Bars represent \% of MiaPaCa-2 cells in G0/G1-phase, S-phase, or G2/M-phase (mean \pm s.e.m.). 72h post-transfection with either ns-siRNA or $\beta I I I-T u b ~ s i R N A$ cells were incubated for eight hours with Paclitaxel (C) or Vincristine (D). Asterisks indicate significance relative to the no drug control of the same $\operatorname{siRNA}(* \mathrm{p} \leq 0.05, * * * \mathrm{p} \leq 0.001, * * * * \mathrm{p} \leq 0.0001 ; \mathrm{n}=5)$. 
or control siRNA (ns-siRNA) and then grown in softagar for 14 days. Knockdown of $\beta$ III-tubulin significantly reduced the number of cell colonies formed (Figure 6B and $6 \mathrm{C}$ ). Finally, to investigate whether the reduction in cell colonies was in part due to anoikis, MiaPaCa-2 cells transfected with control or $\beta$ III-tubulin siRNA were cultured in suspension for $48 \mathrm{~h}$. We observed a significant increase in the apoptotic fraction of $\mathrm{MiaPaCa}-2$ cells with knockdown of $\beta$ III-tubulin (Figure 6D). Collectively, these results provide strong evidence that $\beta$ III-tubulin plays an important role in promoting the growth and metastatic potential of pancreatic cancer cells.
Stable suppression of $\beta$ III-tubulin reduces tumor growth and metastases in an orthotopic murine model of pancreatic cancer

To extend our findings in vivo, we generated MiaPaCa-2 cells that stably expressed luciferase and a $\beta$ III-tubulin shRNA construct. Cells stably expressing the same construct but with a non-functional shRNA (nsshRNA) served as controls. These cells possessed potent knockdown of $\beta$ III-tubulin compared to control shRNA cells (Supplementary Figure 5A and 5B). Notably, cells with stable suppression of $\beta$ III-tubulin had a significant

\section{MiaPaCa-2}

A

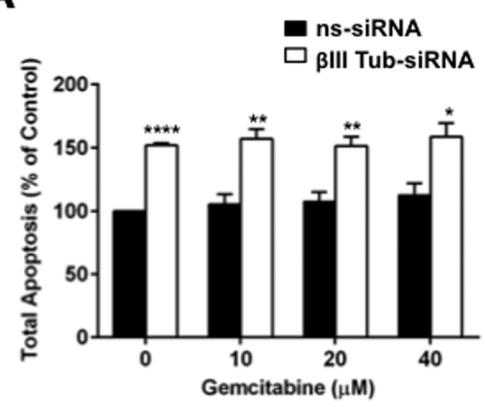

B

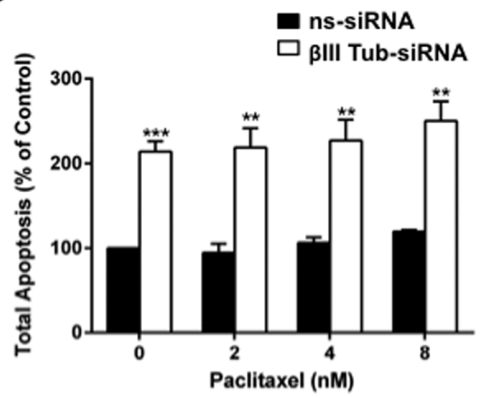

C

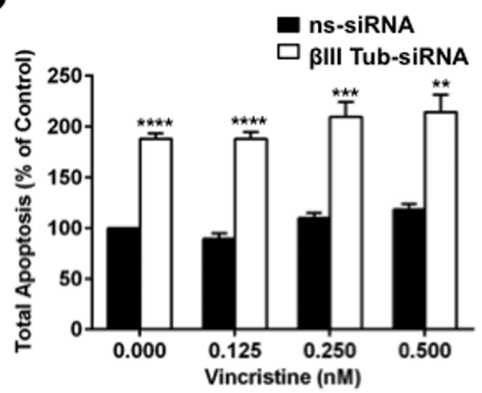

D

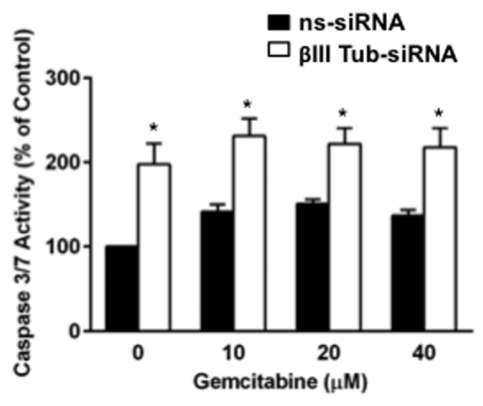

E

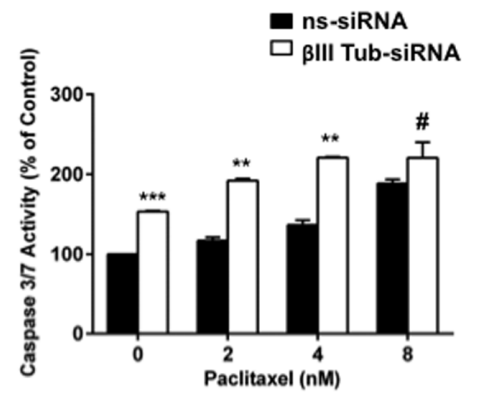

$\mathbf{F}$

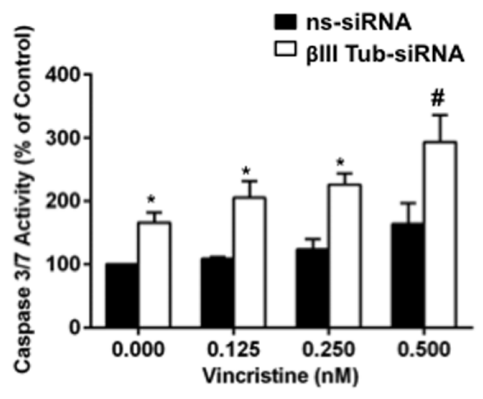

FIGURE 5: $\boldsymbol{\beta}$ III-tubulin silencing induces apoptosis in MiaPaCa-2 cells. A-C) MiaPaCa-2 cells transfected with control siRNA (ns-siRNA) or $\beta$ III-tubulin siRNA ( $\beta$ III-Tub siRNA). 48h post-transfection cells were cultured in titrations of Gemcitabine (A), Paclitaxel (B), or Vincristine (C) for 24h. Bars represent the fraction of total MiaPaCa-2 cells that are apoptotic (mean+s.e.m. as a \% of ns-siRNA no drug control) as determined by Annexin V and 7AAD staining. Asterisks indicate significance relative to ns-siRNA controls of the same drug dose $(* \mathrm{p} \leq 0.05, * * \mathrm{p} \leq 0.01, * * * \mathrm{p} \leq 0.001 ; \mathrm{n}=3-4)$. D-F) MiaPaCa-2 cells transfected with ns-siRNA or $\beta$ III-Tub siRNA were cultured in titrations of Gemcitabine (D), Paclitaxel (E), or Vincristine (F) for 24h. Bars represent caspase 3/7 activity (mean \pm s.e.m. as a \% of nssiRNA no drug control). Asterisks indicate significance relative to ns-siRNA controls of the same drug dose $(* \mathrm{p} \leq 0.05, * * \mathrm{p} \leq 0.01, * * *$ $\mathrm{p} \leq 0.001 ; \mathrm{n}=4-5)$. 
decrease in anchorage-independent growth when compared to controls (ns-shRNA) (Figure 7A). These results concurred with our data using transient knockdown of $\beta$ III-tubulin (Figure 6B). Cells were implanted into the pancreas of mice, and allowed to grow for 8 weeks before tumors along with the spleen, liver, kidneys, intestines, and heart/lungs were harvested together with any lymph nodes that exhibited signs of metastases. BIII-tubulin knockdown in the tumors ( 8 weeks post implantation) containing $\beta$ III-tubulin shRNA was confirmed (Figures 7B-7D). Pancreatic tumors expressing $\beta$ III-tubulin shRNA had significantly reduced tumor volume relative to control shRNA tumors (Control: $145.0 \pm 30.5 \mathrm{~mm}^{3}$, $\beta$ III-Tubulin shRNA: $80.6 \pm 21.9 \mathrm{~mm}^{3}, \mathrm{p}<0.05$; Figure $\left.8 \mathrm{~A}-\mathrm{B}\right)$. The incidence of metastases was reduced by $30 \%$ in mice with tumors expressing $\beta$ III-tubulin shRNA (4/10 mice had metastases) versus tumors expressing control shRNA (7/10 mice had metastases). Metastases that were detected by ex vivo imaging of individual organs on a Xenogen IVIS platform (Supplementary Figure 6A) were found to be reduced by $62.5 \%$ in the $\beta$ III-tubulin shRNA pancreatic tumors, relative to controls (Figure 8C-D). Metastases detected by ex vivo imaging were confirmed by histology (Supplementary Figure 6B) and immunohistochemistry (Supplementary Figure 6C).

\section{DISCUSSION}

Pancreatic cancer is chemoresistant and metastatic, making this a lethal cancer. There is mounting evidence to

\section{A Anchorage- Dependent Growth}
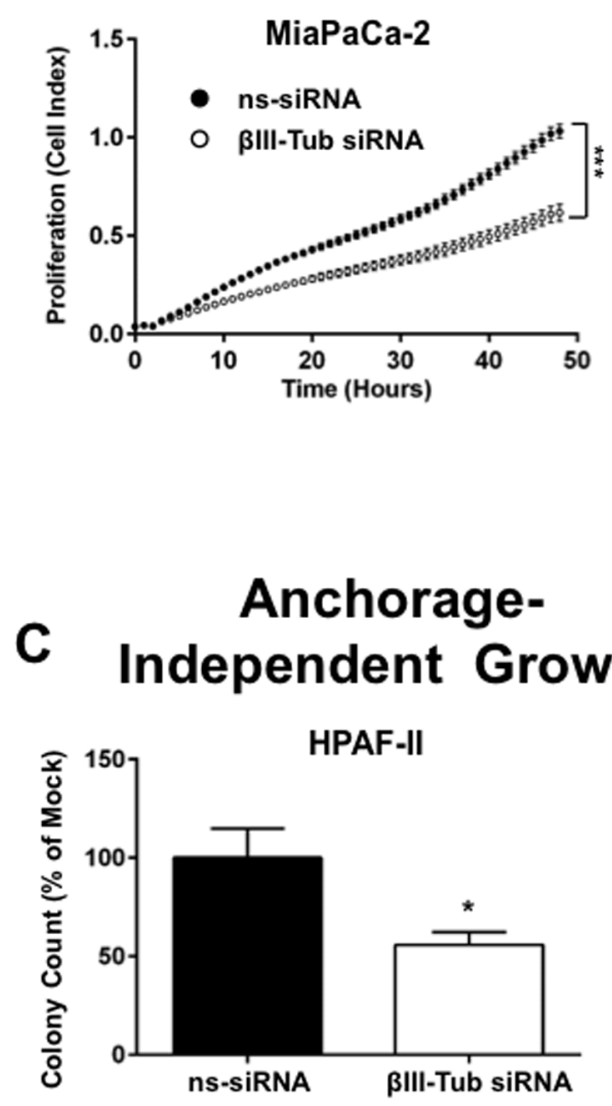

B
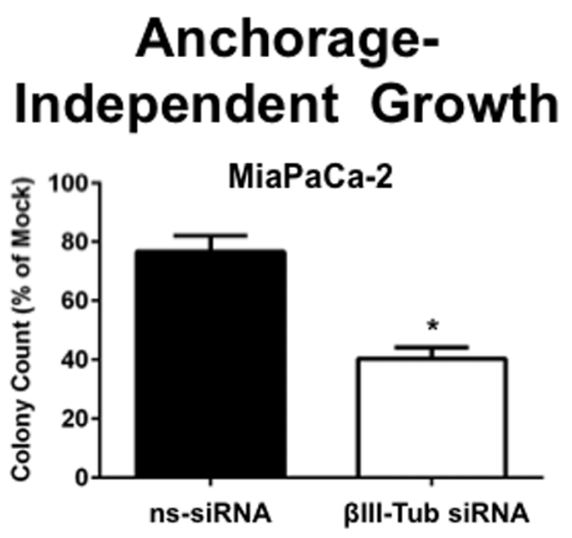

Anoikis

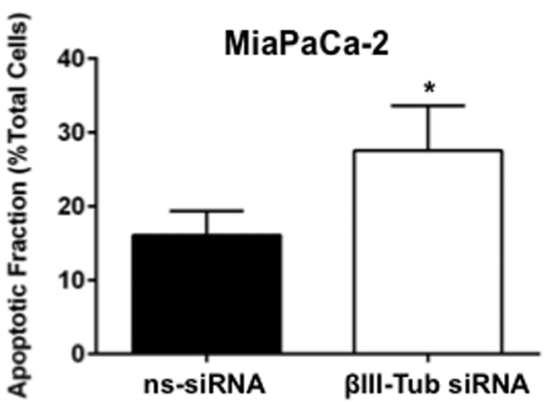

FIGURE 6: $\beta$ III-tubulin silencing reduces both anchorage dependent and independent pancreatic cancer cell growth. A) xCelligence assay of MiaPaCa-2 cells transfected with ns-siRNA or $\beta I I I-t u b u l i n$ siRNA ( $\beta I I I-T u b$ siRNA). 72h post-transfection cells were seeded into xCelligence plates. Circles represent cell index (mean \pm s.e.m.) at hourly time points, and are directly related to cell number. Asterisks indicate significance $(* * * \mathrm{p} \leq 0.001 ; \mathrm{n}=3)$. B) MiaPaCa-2 cells transfected with mock, ns-siRNA or $\beta$ III-Tubulin siRNA were embedded in soft-agarose at $48 \mathrm{~h}$ post-transfection and allowed to form colonies. Bars represent the number of colonies that formed (mean+s.e.m. as a $\%$ of mock). Asterisks indicate significance $\left({ }^{*} \mathrm{p} \leq 0.05 ; \mathrm{n}=3\right)$. C) As per $\mathrm{B}$, except experiments were carried out with HPAF-II cells ( $* \mathrm{p} \leq 0.05 ; n=3)$. D) MiaPaCa-2 cells were transfected with ns-siRNA or $\beta$ III-tubulin siRNA and $24 \mathrm{~h}$ post-transfection cells were cultured under anchorage independent conditions for a further $48 \mathrm{~h}$ (wells coated with Poly-HEMA). Bars represent the apoptotic fraction determined by Annexin V and 7AAD staining (mean \pm s.e.m.). Asterisks indicate significance $(* * * \mathrm{p} \leq 0.001 ; \mathrm{n}=3$ ). 
show that $\beta$ III-tubulin is dysregulated in tumor cells, and its increased expression is correlated to poor survival [3033]. However, the role of $\beta$ III-tubulin in pancreatic cancer is unknown. We report novel functions for $\beta$ III-tubulin in regulating pancreatic cancer cell growth and survival in the absence and presence of chemotherapeutic drugs. In addition, we demonstrate that silencing $\beta$ III-tubulin expression in pancreatic cancer cells results in reduced tumor growth and metastases in vivo.

In health, $\beta$ III-tubulin expression is restricted to neuronal tissue and testicular sertoli cells $[19,20]$. However, clinical studies report high levels of $\beta$ IIItubulin in different tumors including breast, lung, ovarian, gastric and melanoma [13-18]. Recently, high $\beta$ III-tubulin expression was reported in prostate cancer, and was linked to high Gleason grade, advanced tumor stage and local

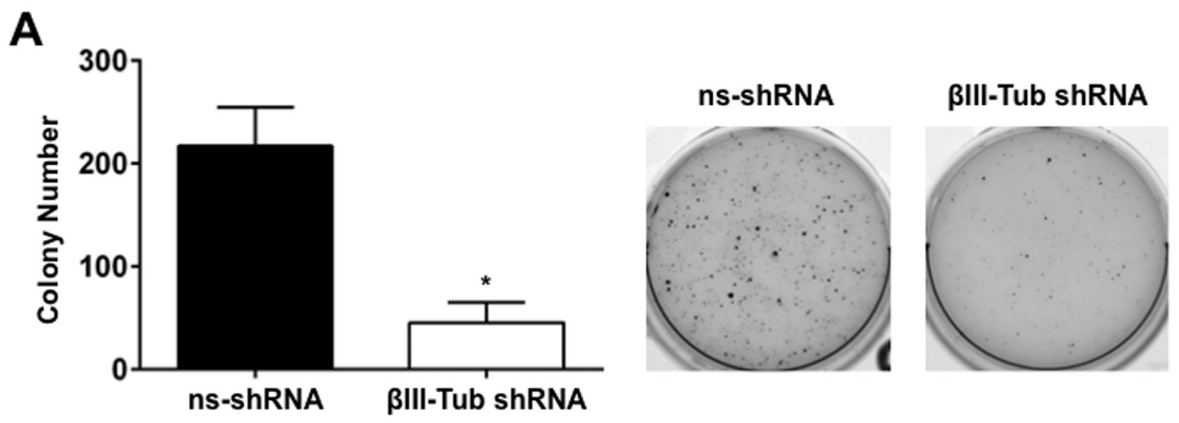

B

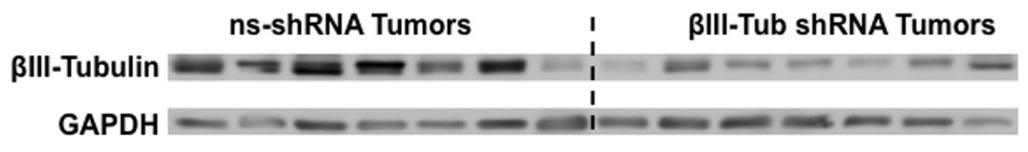

C

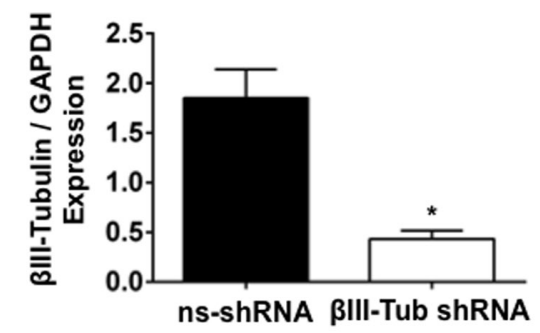

D

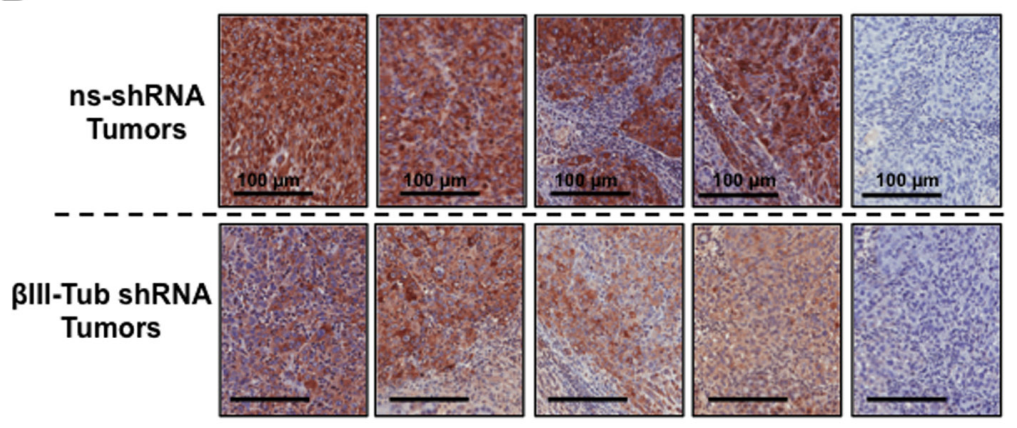

FIGURE 7: $\beta$ III-tubulin shRNA expressing MiaPaCa-2 cells have reduced anchorage-independent growth and potent long-term $\beta$ III-tubulin knockdown in vivo. A) MiaPaCa-2 cells stably expressing $\beta I I I-T u b u l i n$ ( $\beta$ III-Tub) or control shRNA (nsshRNA) were embedded in soft-agarose and allowed to form colonies. Bars represent the number of colonies that formed $(* \mathrm{p} \leq 0.05$; $\mathrm{n}=3$ ). Representative micrographs showing colony formation in MiaPaca-2 cells stably expressing control (ns-shRNA) or $\beta$ III-Tubulin

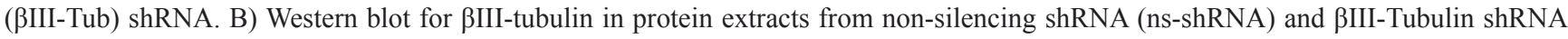
( $\beta$ III-Tub shRNA) tumors after eight weeks of in vivo growth. GAPDH was used as a loading control. C) Densitometry analysis of $\beta$ IIItubulin expression normalized to GAPDH expression demonstrates that $\beta$ III-tubulin is significantly decreased in pancreatic tumors stably expressing $\beta$ III-tubulin shRNA compared to control (ns-shRNA) expressing tumors $\left({ }^{*} \mathrm{p}<0.05 ; \mathrm{n}=7\right.$ ). D) Immunohistochemistry for $\beta$ IIItubulin in tissue sections from primary tumors expressing (i-v) ns-shRNA or (vi-ix) $\beta$ III-Tubulin shRNA. 
metastases [31]. In this study we demonstrated that $\beta$ IIItubulin was expressed at high levels in pancreatic tumor cells, while absent in the acinar and normal pancreatic ducts in tissue specimens collected after surgical resection. We also showed increased expression of $\beta$ III-tubulin in pancreatic cancer cell lines compared to primary cultures of HPDE cells. Our results are in accordance with a study by Lee et al. [26], which reported $\beta$ III-tubulin expression in advanced PDA tissue samples. However, prior to the present study, there have been no studies to elucidate its functional role.

Using RNAi we demonstrated that silencing $\beta$ IIItubulin in pancreatic cancer cells reduced their ability to form cell colonies. Moreover, the number of colonies was further reduced when the cells were treated with different chemotherapy drugs including, the anti-metabolite gemcitabine (used in the first-line treatment of pancreatic cancer) and the TBAs paclitaxel and vincristine [albumin bound paclitaxel (Abraxane) is now used in the clinic to treat pancreatic cancer and vincristine while not a pancreatic cancer treatment, was used in this study to help delineate $\beta$ III-tubulin's function]. Knockdown of $\beta$ II-tubulin, which was also overexpressed in pancreatic cancer cells, had no effect on the clonogenic potential of pancreatic cancer cells in the absence or presence of chemotherapy drugs. This result is in contrast to a previous study in NSCLC cells which showed that silencing $\beta I I-$ tubulin expression increased sensitivity to Vinca alkaloids (25). Therefore, it is possible that the ability of pancreatic cancer cells to form colonies in the absence or presence

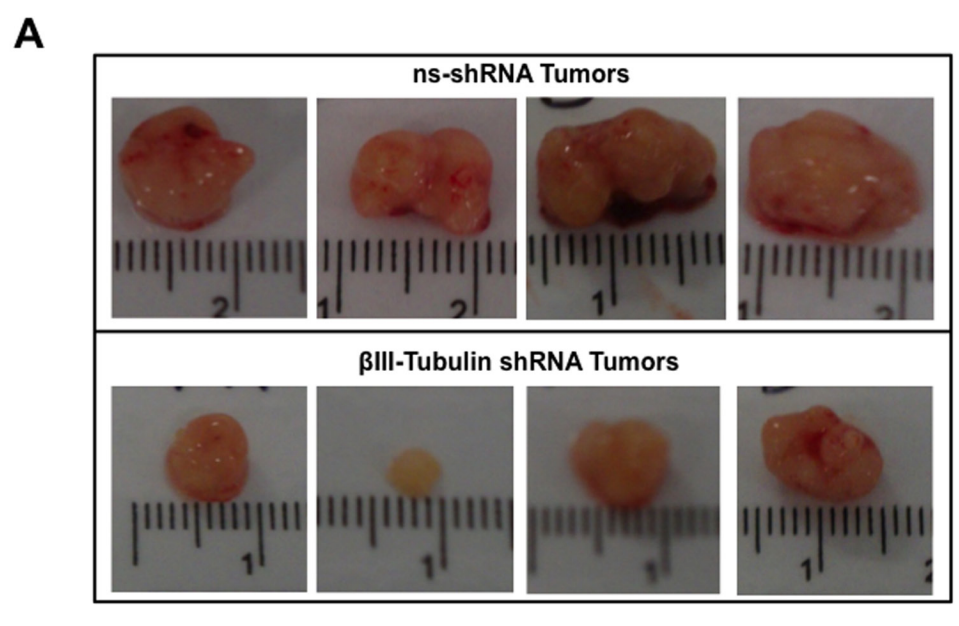

B

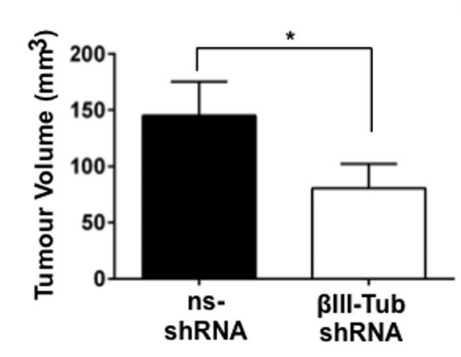

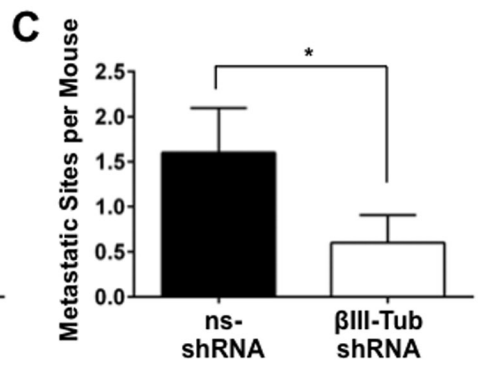

D

\begin{tabular}{|l|c|c|}
\hline \multicolumn{3}{|c|}{ Incidence of Metastases (Number of animals with metastases) } \\
\hline Metastatic sites & ns-shRNA $(\mathrm{n}=10)$ & $\beta$ III-Tub shRNA $(\mathrm{n}=10)$ \\
\hline Spleen & 5 & 1 \\
\hline Liver & 3 & 2 \\
\hline Lung & 1 & 1 \\
\hline Intestine & 5 & 2 \\
\hline Lymph node & 2 & 0 \\
\hline Total & 16 & 6 \\
\hline
\end{tabular}

FIGURE 8: The effect of $\beta$ III-tubulin silencing on orthotopic tumor growth and metastases. A) Representative photomicrographs of primary tumors expressing control (ns-shRNA) or $\beta$ III-tubulin ( $\beta$ III-Tub) shRNA eight weeks post-implantation ( $\mathrm{n}=4$ individual mice per group). B) Bars represent tumor volume (mean \pm s.e.m.) of primary pancreatic tumors eight weeks post-implantation. Asterisks indicate significance $(* \mathrm{p} \leq 0.05 ; \mathrm{n}=9$ for $\mathrm{ns}$-shRNA and $\mathrm{n}=10$ for $\beta$ III-tubulin shRNA). C) Bars represent the number of metastatic sites per mouse (mean \pm s.e.m.) eight weeks post-implantation. Asterisks indicate significance $\left({ }^{*} p \leq 0.05\right)$. D) Table showing the total number of metastases detected in each organ for ns-shRNA and $\beta I I I-T u b$ shRNA tumors. 
of chemotherapy drugs may be $\beta$-tubulin isotype specific. Moreover, $\beta$ III-tubulin appears to have a tumor cellspecific effect as silencing its expression in normal HPDE cells had no effect on their cell viability or proliferation.

A role for $\beta$-tubulin isotypes in regulating chemosensitivity in tumor cells has been described. Gan et al. [22] showed that silencing BIII-tubulin in NSCLC cells reduced their clonogenic capacity in the presence of chemotherapy. This finding was extended to an in vivo setting by McCarroll et al. [24], which reported that stable suppression of $\beta$ III-tubulin in NSCLC cells increased survival in mice when treated with cisplatin. More recently, $\beta$ III-tubulin was shown to be involved in regulating docetaxel sensitivity in castrate-resistant prostate cancer cells [31]. Interestingly, Gan et al. [28] reported that suppression of $\beta \mathrm{II}-$ or $\beta \mathrm{IVb}$-tubulin in NSCLC cells increased sensitivity to only one class of chemotherapy drugs known as Vinca Alkaloids. These studies reinforce the concept that individual $\beta$-tubulin isotypes may have specific functional roles in tumor cells, with $\beta$ III-tubulin appearing to be important in regulating sensitivity to broad classes of chemotherapy drugs. However, despite the increasing number of studies that highlight the importance of $\beta$ III-tubulin in tumor cells, its mode of action has yet to be fully determined.

In an attempt to understand how BIII-tubulin is exerting its effect on pancreatic cancer cells we first examined whether silencing its expression influenced the structural integrity of the microtubule cytoskeleton, given the importance of microtubule proteins in regulating the shape and structure of cells. Silencing $\beta$ III-tubulin expression in pancreatic cancer cells had no effect on the structure of the microtubule cytoskeleton. Next, we assessed whether silencing $\beta$ III-tubulin impacted the cell cycle given the importance of microtubule proteins in regulating mitosis. No significant effect on the cell cycle was observed. We also showed that silencing $\beta$ IIItubulin did not potentiate the anti-mitotic effect of TBAs in pancreatic cancer cells. Together, these results indicate that the observed decrease in the clonogenic potential of pancreatic cancer cells with suppressed $\beta$ III-tubulin in the absence or presence of chemotherapeutic drugs does not involve modulation of the microtubule cytoskeleton or the cell cycle.

Finally, to determine whether this decrease in the clonogenic potential of pancreatic cancer cells with suppressed $\beta$ III-tubulin was due to increased sensitivity to cell death, we measured apoptosis in pancreatic cancer cells. We demonstrated that silencing $\beta$ III-tubulin induced cell death in pancreatic cancer cells which was sustained in the presence of chemotherapy. It appeared that the intrinsic apoptotic pathway was involved as evidenced by increased caspase $3 / 7$ activity. This is the first study to report a significant induction of apoptosis in tumor cells with suppressed $\beta$ III-tubulin in the absence of cellular stress. Previously, induction of apoptosis in tumor cells with knockdown of $\beta$ III-tubulin was observed only when cells were treated with chemotherapeutic drugs [22, 24]. Therefore, it appears that pancreatic cancer cells are highly sensitive to suppression of $\beta$ III-tubulin, and that this protein may provide these cells with a survival advantage. Indeed, evidence in other cell types suggest that $\beta$ III-tubulin may be part of a cell survival pathway. For instance, its expression levels can be modulated by different types of cell stress. In two separate studies, Raspaglio et al [34, 35] demonstrated increased BIIItubulin expression in ovarian cancer cells exposed to hypoxia or nutrient deprivation. Under these conditions $\beta$ III-tubulin was shown to bind to important signaling proteins such as pro-survival kinase PIM1 [36]. This protein kinase is involved in promoting chemoresistance, and its expression levels have been correlated with aggressive disease in pancreatic cancer [37, 38]. Therefore, it is possible that the increased levels of $\beta$ IIItubulin allow for PIM1 to exert its pro-survival effect in pancreatic cancer cells. In addition, a glycosylated and phosphorylated form of $\beta$ III-tubulin has been identified in the mitochondria of cancer cells [39]. It may be possible that $\beta$ III-tubulin is involved in modulating apoptosis via the mitochondria. Studies aimed at understanding how $\beta$ III-tubulin hypersensitizes pancreatic cancer cells to apoptosis are under investigation in our laboratory.

To determine whether suppression of $\beta$ III-tubulin would affect the tumorigenic and metastatic potential of pancreatic cancer cells, we silenced $\beta$ III-tubulin expression in pancreatic cancer cells and measured anchorage-dependent and independent-cell growth. Knockdown of $\beta$ III-tubulin resulted in a significant reduction in anchorage-dependent and independent growth. The decrease in anchorage-independent cell growth was associated with increased anoikis (anchorageindependent apoptosis), reinforcing the link between $\beta$ IIItubulin silencing and induction of apoptosis in pancreatic cancer cells. Indeed, tumor cells with high metastatic potential have developed mechanisms of resistance to this form of apoptosis [40]. To establish whether the decreased tumorigenic potential in pancreatic cancer cells with suppressed $\beta$ III-tubulin would translate in vivo, we generated pancreatic cancer cells which stably expressed $\beta$ III-tubulin shRNA. We showed for the first time that when these cells were implanted into the pancreas of mice there was decreased primary tumor growth and metastases. Together, these data demonstrate that $\beta$ IIItubulin is important in providing pancreatic cancer cells with a key survival advantage, thus allowing them to grow and metastasize.

Collectively, this work has identified a novel role for $\beta$ III-tubulin in promoting pancreatic cancer growth and survival. Identification of $\beta$ III-tubulin as a therapeutic target has the potential to refine personalized medicine for patients with this malignancy. The relatively limited impact of chemotherapy in this malignancy does require 
identification of agents with alternative anti-tumor activity. Drugs targeting this system would be predicted to have limited effects on normal tissues. Therefore they lend themselves to prolonged use, such as in the adjuvant setting. In particular the anti-metastatic effect shown in vivo encourages exploration of their use in the adjuvant setting and in conjunction with or sequential to chemotherapy.

\section{MATERIALS AND METHODS}

\section{Cell culture}

Human pancreatic cancer cells (MiaPaCa-2, Panc1 and HPAF-II) were obtained from ATCC and cultured as described [41]. Normal Human Pancreatic Ductal Epithelial (HPDE) cells (a kind gift from Ming Tsao, Ontario Cancer Institute) were grown in Keratinocyteserum-free (KSF) medium supplemented with $50 \mathrm{mg} /$ $\mathrm{ml}$ bovine pituitary extract (BPE) and $5 \mathrm{ng} / \mathrm{ml}$ epidermal growth factor (EGF) as described [42].

\section{Immunohistochemistry}

Human PDA tissue specimens were collected by surgical removal. The use of these sections was approved by UNSW Human Research Ethics Committee (HCEC\# HC14039). Immunohistochemistry was performed on paraffin-embedded human or mouse tumor tissue sections as described [24, 41, 43]. Antibodies used were, anti$\beta$ III-tubulin (1:200) (Chemicon), anti- $\beta$ II-tubulin (1:200) (Covance), anti-luciferase (1:50) (Biovision incorporated).

\section{siRNA transfection}

Pancreatic cancer cells and HPDE cells were transfected with siRNAs using Lipofectamine 2000 (Invitrogen). All cells were transfected with smart pool On-Target Plus siRNAs designed against $\beta$ III-Tubulin (Thermoscientific, Cat. L-008260-00), $\beta$ III-Tubulin (Thermoscientific, Cat. L-020099-00), or non-silencing control (Thermoscientific, Cat. D-001810-10-20).

\section{Real time quantitative PCR (qPCR)}

Total RNA was extracted from pancreatic cancer cells and HPDEs, and transcribed to cDNA as described [24, 43]. qPCR was performed using the QuantiFast SYBR Green PCR kit (Qiagen) as described [24, 43]. Primer sequences were: $\beta$ III-Tubulin forward primer, 5'-GCGAGATGTACGAAGACGAC-3'; $\quad \beta$ III-Tubulin reverse primer, 5'-TTTAGACACTGCTGGCTTCG-3'; $\beta$ II-Tubulin forward primer,

\section{5'-AAAGAATTCGACGCCACGGCCGACGAA}

CAAGGG-3'; $\quad$ III-Tubulin reverse primer, 5'-AAAAGCTTACAAACGTTTATGTGATTTTAG-3'.

All data were normalized to the $18 \mathrm{~S}$ gene (Quantitect Primer Assay, Qiagen).

\section{Western blot analysis}

Western blot analysis was performed using the following antibodies: anti- $\beta$ III-tubulin (Chemicon), anti$\beta$ II-tubulin (Covance), anti- $\beta$ I-tubulin (Covance) and anti-GAPDH (Abcam) as described [22, 24, 28]. The blots were scanned using LAS4000 scanner and quantified using ImageQuant TL (GE Healthcare).

\section{Immunofluorescence staining}

24h post-transfection with siRNA, cells were seeded onto glass chamber slides and allowed to adhere for 48h. The slides were fixed in 4\% paraformaldehyde and immunofluorescence staining was performed as described $[22,43,44]$. Primary and secondary antibodies used were, anti- $\beta$ III-tubulin (1:500), anti- $\alpha$-tubulin (1:500), anti-goat AlexaFluor-488 or AlexaFluor-555 (1:1000). Images were captured using a Leica confocal microscope.

\section{Cell proliferation assays}

HPDE cell proliferation was measured $72 \mathrm{~h}$ posttransfection using the Cell Counting Kit-8 (CCK-8) kit (Dojindo) as described [24, 41]. MiaPaCa-2 proliferation was measured on an xCELLigence platform (ACEA Biosciences). Cells were seeded $72 \mathrm{~h}$ post-transfection at 3000 cells/well into 96-well E-Plates (ACEA Biosciences), then transferred into an xCELLigence in a humidified $37^{\circ} \mathrm{C}$ chamber in $5 \% \mathrm{CO}_{2}$. Cell Index (Proliferation) was measured hourly for $48 \mathrm{~h}$.

\section{Cytotoxic drug-clonogenic assays}

Following siRNA transfection cytotoxic drugclonogenic assays were performed as described [22, 24, 28].

\section{Cell cycle analysis}

$72 \mathrm{~h}$ post siRNA transfection, MiaPaCa- 2 cells were incubated in Taxol (0-40 nM) or Vincristine (0-10 nM) for $8 \mathrm{~h}$, and cell cycle measured as described [44]. 


\section{Detection of apoptosis}

48h after siRNA transfection, pancreatic cancer cells were treated with culture medium containing cytotoxic drugs for 24h. Cell death was measured using the Annexin V-PE-7-AAD-FITC reagent (Millipore) as described $[41,45,46]$. Caspase $3 / 7$ activity was analyzed using a Caspase-Glo luminescent based assay as previously described [24, 41]. Briefly, pancreatic cancer cells were treated with siRNA as above and seeded into a 96-well white opaque plate and a corresponding clear 96-well plate. $24 \mathrm{~h}$ post-cytotoxic drug treatment, cells in the white opaque plate were incubated with caspase $3 / 7$ reagent for $2 \mathrm{~h}$ at room temperature and luminescence measured with a luminometer (PerkinElmer Victor 3). Cells in the clear 96-well plate were incubated with CCK-8 reagent for $1 \mathrm{~h}$ at room temperature and cell viability was determined by measuring absorbance at $450 \mathrm{~nm}$. Caspase $3 / 7$ activity was then normalized to these values.

\section{Soft-agar assay}

MiaPaCa-2 and HPAF-II cells were seeded in $0.33 \%$ agar in $\mathrm{X} 2$ growth medium on a $5 \%$ agar layer in 6 well plates, $48 \mathrm{~h}$ post-siRNA transfection. Colonies were allowed to grow over 3 weeks, after which plates were stained with MTT and visualized on an ImageQuant LAS4000 luminometer (GE Healthcare). Colonies were counted as described [24].

\section{Anoikis assay}

$1 \mathrm{ml}$ of $12 \mathrm{mg} / \mathrm{ml}$ poly 2-hyroxyethyl methacrylate (Poly-HEMA) in 95\% ethanol was added into each well of a 6-well culture plate and left to dry overnight. $24 \mathrm{~h}$ after siRNA transfection MiaPaCa- 2 cells were seeded into the Poly-HEMA-coated wells. Cell death was measured $48 \mathrm{~h}$ later by annexin V-7AAD staining.

\section{Generation of $\beta$ III-tubulin stable short hairpin RNA (shRNA)-luciferase expressing cells}

MiaPaCa-2 cells were first transfected with 2 $\mu \mathrm{g}$ of pGL4.50 (Mammalian Luciferase, Promega) using lipofectamine 2000. Clones with stable integration of the construct were isolated. A stable luciferase-expressing line was transfected with 2 $\mu \mathrm{g}$ of pGFP-V-RS empty vector (negative control), pGFP-V-RS vector containing $\beta$ III-tubulin shRNA (5'-CAGCAGATGTTCGATGCCAAGAACATGAT-3') or pGFP-V-RS vector containing a non-effective shRNA (5'-GCACTACCAGAGCTAACTCAGATAGTACT-3') (OriGENE) using lipofectamine 2000. Three days after transfection, the integration of the shRNA plasmid was verified by measuring $\beta$ III-tubulin expression. GFPhi cells were sorted on a BD Influx Cell Sorter and propagated for 2 weeks in $1 \mu \mathrm{g} / \mathrm{ml}$ puromycin.

\section{Orthotopic pancreatic cancer mouse model}

6-8 week old BALB/c nude mice were used. All animal experiments were approved by the Animal Ethics committee, UNSW (ACEC 12/7B). MiaPaCa-2 cells $\left(1 \mathrm{X} 10^{6}\right)$ were implanted into the tail of the pancreas of mice as described [41, 46]. After 8 weeks, mice were sacrificed and pancreatic tumors, spleen, liver, kidneys, Intestines, heart and lungs and any enlarged lymph nodes/ other organs with signs of metastases were collected. Primary tumor size was measured using microcallipers as described [24, 43]. Metastases were confirmed by macroscopic observation, post-harvest individual organ ex-vivo bioluminescence on the Xenogen IVIS Lumina, as described [47].

\section{Statistical Analyses}

Data are expressed as mean \pm standard error of the mean (SEM) and analyzed where appropriate using ANOVA followed by parametric Dunnett, or Student's $t$ test followed by the nonparametric Wilcoxin test using the GraphPad Prism program. $P<0.05$ was considered statistically significant.

\section{ACKNOWLEDGEMENTS}

This work was supported by grants from the National Health and Medical Research Council (NHMRC; P A. Phillips, J McCarroll, M Kavallaris and D Goldstein; APP1024895), Cancer Council New South Wales (P A. Phillips, J McCarroll, M Kavallaris and D Goldstein), Cure Cancer Australia Foundation Grant (P A. Phillips), Cancer Institute NSW Fellowship (J McCarroll, G Sharbeen), NHMRC CDF Fellowship (P A. Phillips, APP1024896) and NHMRC Senior Research Fellowship (Maria Kavallaris, APP1058299).

\section{Conflict of Interest Statement}

No potential conflicts of interest to disclose.

\section{REFERENCES}

1. Hidalgo M. Pancreatic cancer. The New England journal of medicine. 2010; 362(17):1605-1617.

2. Klein AP. Genetic susceptibility to pancreatic cancer. Molecular carcinogenesis. 2012; 51(1):14-24.

3. Rahib L, Smith BD, Aizenberg R, Rosenzweig AB, Fleshman JM and Matrisian LM. Projecting cancer 
incidence and deaths to 2030: the unexpected burden of thyroid, liver, and pancreas cancers in the United States. Cancer research. 2014; 74(11):2913-2921.

4. Siegel R, Naishadham D and Jemal A. Cancer statistics, 2013. CA: a cancer journal for clinicians. 2013; 63(1):1130 .

5. Vincent A, Herman J, Schulick R, Hruban RH and Goggins M. Pancreatic cancer. Lancet. 2011; 378(9791):607-620.

6. Philip PA, Mooney M, Jaffe D, Eckhardt G, Moore M, Meropol N, Emens L, O'Reilly E, Korc M, Ellis L, Benedetti J, Rothenberg M, Willett C, Tempero M, Lowy A, Abbruzzese J, et al. Consensus report of the national cancer institute clinical trials planning meeting on pancreas cancer treatment. Journal of clinical oncology : official journal of the American Society of Clinical Oncology. 2009; 27(33):5660-5669.

7. Raimondi S, Maisonneuve $\mathrm{P}$ and Lowenfels $\mathrm{AB}$. Epidemiology of pancreatic cancer: an overview. Nature reviews Gastroenterology \& hepatology. 2009; 6(12):699708.

8. Wang Z, Li Y, Ahmad A, Banerjee S, Azmi AS, Kong $D$ and Sarkar FH. Pancreatic cancer: understanding and overcoming chemoresistance. Nature reviews Gastroenterology \& hepatology. 2011; 8(1):27-33.

9. Zalatnai A and Molnar J. Review. Molecular background of chemoresistance in pancreatic cancer. In vivo. 2007; 21(2):339-347.

10. Wolfgang CL, Herman JM, Laheru DA, Klein AP, Erdek MA, Fishman EK and Hruban RH. Recent progress in pancreatic cancer. CA: a cancer journal for clinicians. 2013; 63(5):318-348.

11. Kavallaris M. Microtubules and resistance to tubulinbinding agents. Nature reviews Cancer. 2010; 10(3):194204.

12. Jordan MA and Kamath K. How do microtubule-targeted drugs work? An overview. Current cancer drug targets. 2007; 7(8):730-742.

13. Bernard-Marty C, Treilleux I, Dumontet C, Cardoso F, Fellous A, Gancberg D, Bissery MC, Paesmans M, Larsimont D, Piccart MJ and Di Leo A. Microtubuleassociated parameters as predictive markers of docetaxel activity in advanced breast cancer patients: results of a pilot study. Clinical breast cancer. 2002; 3(5):341-345.

14. Moiseyenko VM, Volkov NM, Suspistin EN, Yanus GA, Iyevleva AG, Kuligina E, Togo AV, Kornilov AV, Ivantsov $\mathrm{AO}$ and Imyanitov EN. Evidence for predictive role of BRCA1 and bTUBIII in gastric cancer. Medical oncology. 2013; 30(2):545.

15. Mozzetti S, Ferlini C, Concolino P, Filippetti F, Raspaglio G, Prislei S, Gallo D, Martinelli E, Ranelletti FO, Ferrandina $\mathrm{G}$ and Scambia G. Class III beta-tubulin overexpression is a prominent mechanism of paclitaxel resistance in ovarian cancer patients. Clinical cancer research : an official journal of the American Association for Cancer Research. 2005;
11(1):298-305.

16. Ranganathan S, Benetatos CA, Colarusso PJ, Dexter DW and Hudes GR. Altered beta-tubulin isotype expression in paclitaxel-resistant human prostate carcinoma cells. British journal of cancer. 1998; 77(4):562-566.

17. Seve $P$ and Dumontet $C$. Is class III beta-tubulin a predictive factor in patients receiving tubulin-binding agents? The lancet oncology. 2008; 9(2):168-175.

18. Seve P, Isaac S, Tredan O, Souquet PJ, Pacheco Y, Perol M, Lafanechere L, Penet A, Peiller EL and Dumontet C. Expression of class III \{beta\}-tubulin is predictive of patient outcome in patients with non-small cell lung cancer receiving vinorelbine-based chemotherapy. Clinical cancer research : an official journal of the American Association for Cancer Research. 2005; 11(15):5481-5486.

19. Guo J, Qiang M and Luduena RF. The distribution of beta-tubulin isotypes in cultured neurons from embryonic, newborn, and adult mouse brains. Brain research. 2011; 1420:8-18.

20. Verdier-Pinard P, Pasquier E, Xiao H, Burd B, Villard C, Lafitte D, Miller LM, Angeletti RH, Horwitz SB and Braguer D. Tubulin proteomics: towards breaking the code. Analytical biochemistry. 2009; 384(2):197-206.

21. Karki R, Mariani M, Andreoli M, He S, Scambia G, Shahabi $\mathrm{S}$ and Ferlini C. betaIII-Tubulin: biomarker of taxane resistance or drug target? Expert opinion on therapeutic targets. 2013; 17(4):461-472.

22. Gan PP, Pasquier E and Kavallaris M. Class III beta-tubulin mediates sensitivity to chemotherapeutic drugs in non small cell lung cancer. Cancer research. 2007; 67(19):9356-9363.

23. Kavallaris M, Burkhart CA and Horwitz SB. Antisense oligonucleotides to class III beta-tubulin sensitize drugresistant cells to Taxol. British journal of cancer. 1999; 80(7):1020-1025.

24. McCarroll JA, Gan PP, Liu M and Kavallaris M. betaIIItubulin is a multifunctional protein involved in drug sensitivity and tumorigenesis in non-small cell lung cancer. Cancer research. 2010; 70(12):4995-5003.

25. Ploussard G, Terry S, Maille P, Allory Y, Sirab N, Kheuang L, Soyeux P, Nicolaiew N, Coppolani E, Paule B, Salomon L, Culine S, Buttyan R, Vacherot F and de la Taille A. Class III beta-tubulin expression predicts prostate tumor aggressiveness and patient response to docetaxel-based chemotherapy. Cancer research. 2010; 70(22):9253-9264.

26. Lee KM, Cao D, Itami A, Pour PM, Hruban RH, Maitra A and Ouellette MM. Class III beta-tubulin, a marker of resistance to paclitaxel, is overexpressed in pancreatic ductal adenocarcinoma and intraepithelial neoplasia. Histopathology. 2007; 51(4):539-546.

27. Dozier JH, Hiser L, Davis JA, Thomas NS, Tucci MA, Benghuzzi HA, Frankfurter A, Correia JJ and Lobert S. Beta class II tubulin predominates in normal and tumor breast tissues. Breast cancer research : BCR. 2003; 5(5):R157-169.

28. Gan PP and Kavallaris M. Tubulin-targeted drug action: 
functional significance of class ii and class IVb betatubulin in vinca alkaloid sensitivity. Cancer research. 2008; 68(23):9817-9824.

29. Hiser L, Aggarwal A, Young R, Frankfurter A, Spano A, Correia JJ and Lobert S. Comparison of beta-tubulin mRNA and protein levels in 12 human cancer cell lines. Cell motility and the cytoskeleton. 2006; 63(1):41-52.

30. Ferrandina G, Zannoni GF, Martinelli E, Paglia A, Gallotta V, Mozzetti S, Scambia G and Ferlini C. Class III betatubulin overexpression is a marker of poor clinical outcome in advanced ovarian cancer patients. Clinical cancer research : an official journal of the American Association for Cancer Research. 2006; 12(9):2774-2779.

31. Tsourlakis MC, Weigand P, Grupp K, Kluth M, Steurer S, Schlomm T, Graefen M, Huland H, Salomon G, Steuber T, Wilczak W, Sirma H, Simon R, Sauter G, Minner S and Quaas A. betaIII-Tubulin Overexpression Is an Independent Predictor of Prostate Cancer Progression Tightly Linked to ERG Fusion Status and PTEN Deletion. The American journal of pathology. 2013.

32. Vilmar AC, Santoni-Rugiu E and Sorensen JB. Class III beta-tubulin in advanced NSCLC of adenocarcinoma subtype predicts superior outcome in a randomized trial. Clinical cancer research : an official journal of the American Association for Cancer Research. 2011; 17(15):5205-5214.

33. Yang YL, Luo XP and Xian L. The Prognostic Role of the Class III beta-Tubulin in Non-Small Cell Lung Cancer (NSCLC) Patients Receiving the Taxane/VinorebineBased Chemotherapy: A Meta-Analysis. PloS one. 2014; 9(4):e93997.

34. Raspaglio G, De Maria I, Filippetti F, Martinelli E, Zannoni GF, Prislei S, Ferrandina G, Shahabi S, Scambia G and Ferlini C. HuR regulates beta-tubulin isotype expression in ovarian cancer. Cancer research. 2010; 70(14):5891-5900.

35. Raspaglio G, Filippetti F, Prislei S, Penci R, De Maria I, Cicchillitti L, Mozzetti S, Scambia G and Ferlini C. Hypoxia induces class III beta-tubulin gene expression by HIF-1alpha binding to its 3' flanking region. Gene. 2008; 409(1-2):100-108.

36. De Donato M, Mariani M, Petrella L, Martinelli E, Zannoni GF, Vellone V, Ferrandina G, Shahabi S, Scambia G and Ferlini C. Class III beta-tubulin and the cytoskeletal gateway for drug resistance in ovarian cancer. Journal of cellular physiology. 2012; 227(3):1034-1041.

37. Reiser-Erkan C, Erkan M, Pan Z, Bekasi S, Giese NA, Streit $\mathrm{S}$, Michalski CW, Friess H and Kleeff J. Hypoxia-inducible proto-oncogene Pim-1 is a prognostic marker in pancreatic ductal adenocarcinoma. Cancer biology \& therapy. 2008; 7(9):1352-1359.

38. $\mathrm{Xu} \mathrm{D}$, Allsop SA, Witherspoon SM, Snider JL, Yeh JJ, Fiordalisi JJ, White CD, Williams D, Cox AD and Baines AT. The oncogenic kinase Pim-1 is modulated by K-Ras signaling and mediates transformed growth and radioresistance in human pancreatic ductal adenocarcinoma cells. Carcinogenesis. 2011; 32(4):488-495.
39. Cicchillitti L, Penci R, Di Michele M, Filippetti F, Rotilio D, Donati MB, Scambia G and Ferlini C. Proteomic characterization of cytoskeletal and mitochondrial class III beta-tubulin. Molecular cancer therapeutics. 2008; 7(7):2070-2079.

40. Taddei ML, Giannoni E, Fiaschi T and Chiarugi P. Anoikis: an emerging hallmark in health and diseases. The Journal of pathology. 2012; 226(2):380-393.

41. Phillips PA, Dudeja V, McCarroll JA, Borja-Cacho D, Dawra RK, Grizzle WE, Vickers SM and Saluja AK. Triptolide induces pancreatic cancer cell death via inhibition of heat shock protein 70. Cancer research. 2007; 67(19):9407-9416.

42. Ouyang H, Mou L, Luk C, Liu N, Karaskova J, Squire J and Tsao MS. Immortal human pancreatic duct epithelial cell lines with near normal genotype and phenotype. The American journal of pathology. 2000; 157(5):1623-1631.

43. Byrne FL, Yang L, Phillips PA, Hansford LM, Fletcher JI, Ormandy CJ, McCarroll JA and Kavallaris M. RNAimediated stathmin suppression reduces lung metastasis in an orthotopic neuroblastoma mouse model. Oncogene. 2014; 33(7):882-890.

44. Gan PP, McCarroll JA, Po'uha ST, Kamath K, Jordan MA and Kavallaris M. Microtubule dynamics, mitotic arrest, and apoptosis: drug-induced differential effects of betaIIItubulin. Molecular cancer therapeutics. 2010; 9(5):13391348.

45. Aghdassi A, Phillips P, Dudeja V, Dhaulakhandi D, Sharif R, Dawra R, Lerch MM and Saluja A. Heat shock protein 70 increases tumorigenicity and inhibits apoptosis in pancreatic adenocarcinoma. Cancer research. 2007; 67(2):616-625.

46. Phillips PA, Sangwan V, Borja-Cacho D, Dudeja V, Vickers SM and Saluja AK. Myricetin induces pancreatic cancer cell death via the induction of apoptosis and inhibition of the phosphatidylinositol 3-kinase (PI3K) signaling pathway. Cancer letters. 2011; 308(2):181-188.

47. McNally LR, Welch DR, Beck BH, Stafford LJ, Long JW, Sellers JC, Huang ZQ, Grizzle WE, Stockard CR, Nash KT and Buchsbaum DJ. KISS1 over-expression suppresses metastasis of pancreatic adenocarcinoma in a xenograft mouse model. Clinical \& experimental metastasis. 2010; 27(8):591-600. 